\title{
Education in Anaesthesia
}

\section{The cost for \\ construction and \\ operation of a \\ simulation centre}

Purpose: Lack of financial information results in planning difficulties and may delay the introduction of simulator based education. We collected data from an existing simulation centre and describe a construction and operating budget to facilitate planning and construction for interested institutions.

Methods: After obtaining approval from the managing board, the plans and financial statements of the Canadian Simulation Centre, Sunnybrook Health Science Centre, University of Toronto were reviewed from the period from July 1994 through June 1996. Costs were calculated from the financial reports and separated into construction and operation phases. A list of the ongoing educational and research activities was compiled.

Results: All dollar figures are expressed in 1996 Canadian Dollars. The planning and construction took place from July 1994 through June 1995 . Construction costs for the simulation centre totalled $\$ 665,000$, of which $85 \%$ was related to capital equipment purchases and $15 \%$ for salary support. The net costs of ongoing education and research activities (3.35 days/week) were \$167,250 from July 1995 through June 1996. About $65 \%$ of this consisted of salary support and was absorbed by the existing educational resources of the University of Toronto Department of Anaesthesia.

Conclusion: Substantial resources are required for the construction of a simulation centre $(\$ 665,000)$ primarily because of capital equipment purchases. However, there is also a considerable operating cost per year $(\$ 167,250)$ which consists mostly of salary support.

Objectif : L'absence de renseignements financiers empêche de planifier et peut même retarder l'implantation de la formation par simulateur. Nous avons obtenu les données d'un centre de simulation établi et nous décrivons sa mise sur pied et son budget de fonctionnement pour en faciliter la planification et l'installation dans d'autres institutions intéressées.

Méthodes : Après l'obtention de l'accord de son comité directeur, nous avons examiné, pour la période de juillet 1994 à juin 1996, les plans et les états financiers du centre canadien de simulation du Sunnybrook Health Centre de l'université de Toronto. Des états financiers distincts consécutifs à la mise sur pied et au fonctionnement ont senvi au calcul des coûts. Nous avons compilé une liste des activités de formation et de recherche.

Résultats : Tous les chiffres exprimés en dollars sont en dollars canadiens de 1996. La planification et la mise sur pied ont eu lieu entre juillet 1994 et juin 1995. Les coûts de construction du centre de simulation ont totalisé $665000 \$$ dont $85 \%$ destinés à l'achat de l'équipement et 15\% aux salaires. Les coûts nets des activités de formation et de recherche (3.35 jours/semaine) ont été de $167250 \$$ de juillet 1995 à juin 1996 . Environ $65 \%$ de ce montant a été versé en salaires et absorbé par les ressources éducationnelles existantes du département d'anesthésie de l'université de Toronto.

Conclusion : La mise sur pied d'un centre de simulation nécessite des ressources substantielles (665 000\$) surtout pour l'achat de l'équipement. II faut toutefois ajouter des coûts de fonctionnement annuels considérables (167250\$) constitués surtout par les salaires.

From the Canadian Simulation Centre for Human Performance and Crisis Management Training, and Department of Anaesthesia, Sunnybrook Health Science Centre, University of Toronto, 2075 Bayview Ave, Toronto, Ontario M4N 3M5.

Address correspondence to: Dr. Matt M. Kurrek; E-mail: m.kurrek@utoronto.ca

Accepted for publication July 21, 1997. 
S IMULATION in health care is a rapidly expanding field and a number of academic centres across Canada may be considering the implementation of simulation based education. Available simulators consist of a realistic mannequin which is controlled by a remote computer (e.g., CAE ${ }^{\mathrm{TM}}$ Electronics, METI ${ }^{\mathrm{TM}}$ ) and simulate a variety of physiological (e.g., heart and breath sounds, pulse, end-tidal carbon dioxide) and pharmacological variables. Applications include the teaching of undergraduate curricula, post-graduate training, $, 1,2$ crisis management training $^{3-5}$ and research in education and human factors. ${ }^{6}$

The purchase price of a simulator (approximately Can $\$ 250,000$ ) is well known, but may only constitute a fraction of the total budget for construction of a centre or for ongoing operating costs. Since there are no published data on construction and maintenance of a simulation centre for health care, we describe a budget based on data from the Canadian Simulation Centre for Human Performance and Crisis Management Training, Sunnybrook Health Science Centre, University of Toronto.

\section{Methods}

After permission was obtained from the managing board, we reviewed the financial plans of the Canadian Simulation Centre for Human Performance and Crisis Management Training at Sunnybrook Health Science Centre, University of Toronto covering the time from July 1994 through June 1996. All costs, including construction, equipment and personnel were included and costs were separated into construction and maintenance phases.

For the construction phase (July 1994 through June 1995), a floor plan was drafted and a detailed construction budget was developed. A capital equipment list was generated and all ancillary equipment including audiovisual equipment were inspected and associated costs were verified. Costs were absorbed by third parties (construction, rent and utilities by the hospital, salaries by the Department of Anaesthesia) in most instances, although some equipment was donated. The purchase price of the donated capital equipment was obtained from the donors. The potential cost of the training of an individual to supervise the centre construction was not included. Also, the cost of the formal instructor training course was not included in the budget. The instructor course was necessary to ensure that enough trained individuals were available to make the centre operational.

For the simulation centre maintenance budget (July 1995 through June 1995), time sheets of the simulation centre's educational and research activities were reviewed and a breakdown of these activities was compiled. Expenses and revenues were verified through review of the centre's accounts and costs absorbed by third parties (rent and utilities by the hospital, salaries by the Department of Anaesthesia) estimated and included. Full time equivalent salaries per annum (FTE, inclusive benefits) were defined: anaesthetist (FTE-ane) $\$ 175,000$, fellow (FTE-fel) $\$ 90,000$, respiratory therapist (FTE-RT) $\$ 30,000$ and secretary (FTE-sec) $\$ 25,000$.

\section{Results}

All dollar figures are reported in 1996 Canadian Dollars. Planning and construction took place from July 1994 through June 1995 and was overseen by an individual with extensive experience in medical simulation at the salary of a clinical fellow. Three existing hospital rooms were redesigned according to the floor plan shown in Figure 1. The centre's layout includes: a simulation room with adjacent control and storage areas, two seminar rooms for debriefing and computer-based instructions, as well as two separate locker rooms (not shown).

The designated hospital area was completely renovated and outfitted with partition drywall, additional

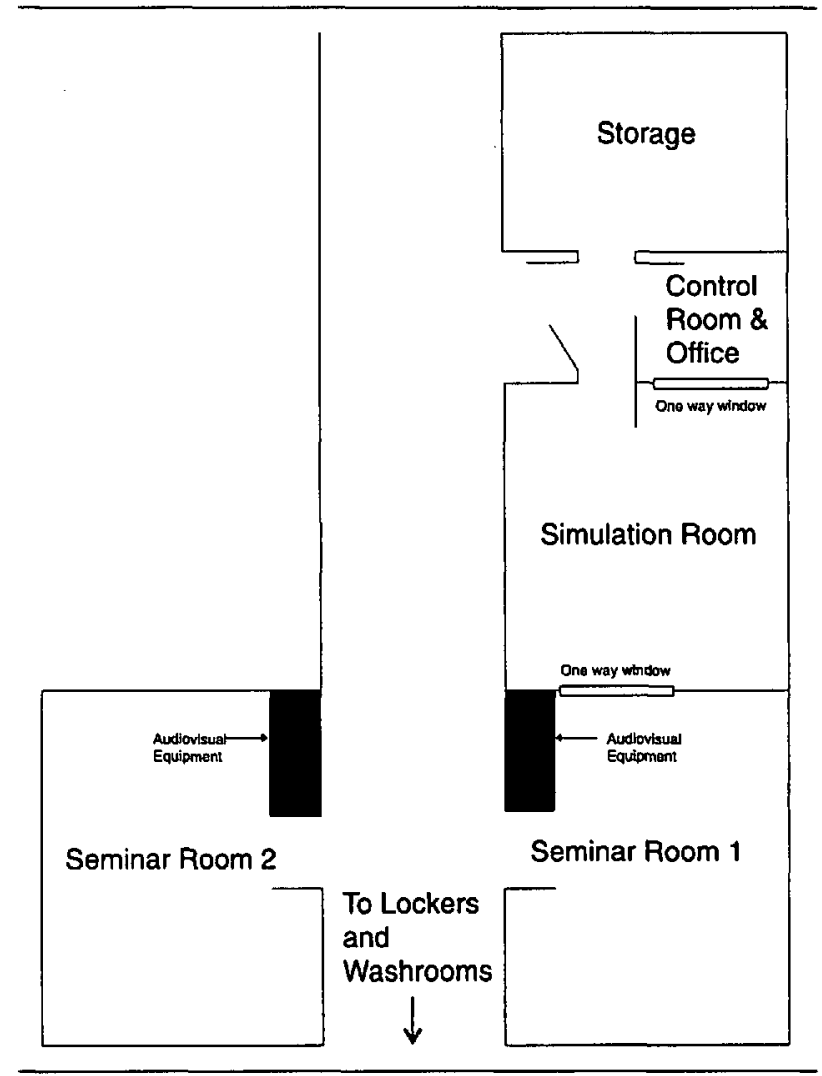

FIGURE 1 Floor plan of the Canadian Simulation Centre 
doors, one way windows, cupboards and shelves, as well as electrical wiring and conduits for audio-visual cables. A medical gas supply for oxygen, medical air and nitrous oxide was constructed. Access to hospital suction and scavenging was provided. Office furniture for the seminar and control rooms, slide projectors with screens, as well as four computers with software were purchased and installed.

Audio-video recordings of the events in the simulation area are generated through two wall-mounted video camcorders with external microphones. The video and audio signals from the cameras are mixed with the output from the monitor processed through a scan converter, audio and video mixer. This allows overlay of values from the monitors onto the real-time video of the simulation. Video playback in the seminar rooms uses standard VCR and TV sets. Two additional video camcorders and VCRs in each seminar room allow recording of lectures and debriefings.

A breakdown of the total construction costs $(\$ 665,000)$ is listed in Table 1 . The purchase price of the CAE ${ }^{\mathrm{TM}}$ - Electronics simulator was $\$ 250,000$ and the various $O R$ equipment ( $O R$ table, anaesthesia machine and monitors) was provided by the donors (approx. \$250,000). Renovations and office equipment totalled $\$ 50,000$ and the purchase and installation of the audio-visual components cost $\$ 25,000$. The salary of a full-time fellow in charge of the construction was $\$ 90,000$.

The ongoing operating and associated costs over the year July 1995 through June 1996 are listed in Table II and III. The centre was used approximately 3.35 days per week between July 1995 through June 1996. The largest components of this use included administrative work (accounting, scheduling etc., 1 day per week at a cost of $\$ 82,437.50$ ) and research ( 1 day per week: cost $-\$ 45,800$ ). The latter is in the area of simulators as an assessment tool, with a projected publication rate of $2-3$ articles per year. Next in line were crisis management training plus course design (0.5 days per week: cost - \$11,887.50) and training of 20 residents each year ( 0.5 days per week: cost $-\$ 22,750)$. The remainder of the time was spent on centre tours ( 0.25 days per week: cost $\$ 7,187.50)$ and full-day corporate training courses for pharmaceutical companies ( 0.1 days per week with a net profit of $\$ 2,812.50)$. Costs per day of use for the various activities are depicted on Figure 2.

\section{Discussion}

A number of academic centres in Canada are interested in adopting simulation technology into their educational and research activities. However, the lack of published financial data, despite anticipated large expenses, makes planning difficult and may delay the introduction of this new and potentially powerful training device.

The construction of the Canadian Simulation Centre in Toronto cost approximately $\$ 665,000$. The largest component (86\%) consisted of capital equipment purchases $(37 \%$ towards the actual mannequin and computer, $37 \%$ towards miscellaneous OR equipment, $7 \%$ towards room renovation and $4 \%$ towards audio-visual equipment). While a large fraction of this cost was absorbed by third parties and donations (c.g., hospital and corporate sponsors), it represented a substantial, non-negotiable fixed expense. The salary cost (14\%) associated with the centre construction was comparatively small and absorbed into academic time. This, however, was based on the availability of an individual

TABLE I Costs for the construction of the Canadian Simulation Centre in Toronto (construction phase: July 1994 through June 1995)

$\begin{aligned} \$ 250,000 & \text { Simulator Purchase } \\ \$ 250,000 & \text { Miscellaneous OR cquipment } \\ \$ 50,000 & \text { Room renovation, office equipment } \\ \$ 25,000 & \text { Audio-visual equipment } \\ \$ 90,000 & \text { FTE-fel (to oversec construction) } \\ \$ 665,000 & \text { TOTAL CONSTRUCTION COSTS }\end{aligned}$

TABLE II Activities of the Canadian Simulation Centrc (maintenance phase: July 1995 through June 1996)

\begin{tabular}{ll}
\hline $1 \mathrm{day} / \mathrm{wk}$ & Administration (accouncing, scheduling, etc.) \\
$1 \mathrm{day} / \mathrm{wk}$ & Research \\
$0.5 \mathrm{day} / \mathrm{wk}$ & Resident Training (20 residents annually) \\
$0.25 \mathrm{day} / \mathrm{wk}$ & Tours (visitors, press conferences, filming etc.) \\
$0.5 \mathrm{day} / \mathrm{wk}$ & Crisis Management Workshops \\
$0.1 \mathrm{day} / \mathrm{wk}$ & Corporate Training \\
$3.35 \mathrm{day} / \mathrm{wk}$ & TOTAL \\
\hline
\end{tabular}

TABLE III Operating costs and personnel requitements of educational and research activities (maintenance phase: July 1995 through June 1996)

\begin{tabular}{|c|c|}
\hline$\$ 82,437.50$ & $\begin{array}{l}\text { Administration ( } 15 \% \text { FTE-ane, } 0.75 \% \text { FTE-sec, } \\
\$ 30,000 \text { rent, } \$ 20,000 \text { simulator upgrades and } \\
\text { maintenance, } \$ 6,000 \text { misc. charges) }\end{array}$ \\
\hline$\$ 45,800.00$ & Research (20\% FTE-ane, 36\% FTE-RT) \\
\hline$\$ 22,750.00$ & Resident Training ( $13 \%$ FTE-ane) \\
\hline$\$ 16,887.50$ & $\begin{array}{l}\text { Crisis Resource Management Workshops } \\
\text { (8\% FTE-ane, 9\% FTE-RT, 0.75\% FTE-sec) }\end{array}$ \\
\hline$(\$ 5,000.00)$ & Net revenue from CRM course fees \\
\hline$\$ 7,187.50$ & Corporate Training ( $4 \%$ FTE-ane, $0.75 \%$ FTE-sec) \\
\hline$(\$ 10,000.00)$ & Net revenue from Corporate Training \\
\hline$\$ 7,187.50$ & Tours ( $4 \%$ FTE-ane, $0.75 \%$ FTE-sec) \\
\hline$\$ 167,250.00$ & NET OPERATING COST \\
\hline
\end{tabular}




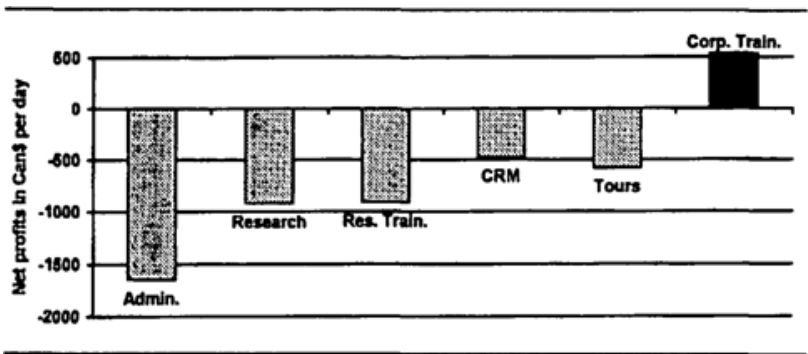

FIGURE 2 Net profit (Canadian \$) normalized per day of use for the various activitics at the Canadian Simulation Centre

with extensive experience in medical simulation, who was recruited for this task. Other centres may have to recruit or alternatively send someone away for training at another simulation centre (at additional cost).

The successful operation of a simulation centre requires the presence of qualified simulator instructors. While advice and experience can be obtained through site visits and consultations with existing centres in North America and elsewhere, this approach can prove time consuming and inefficient. The University of Toronto, Department of Anaesthesia opted for on-site training through The Working Group for Crisis Management Training in Health Care.

The costs of ongoing activities will depend on the commitment of the individual simulation centre. While ongoing expenses are considerable (net costs $\$ 167,250$ for one year 1995 through 1996), they consist to a large extent of salary costs (approximately $70 \%$ of ongoing expenses), which were absorbed into the existing educational resources of the University of Toronto, Department of Anaesthesia.

At the Canadian Simulation Centre, standardized costs (expressed in \$/day) were relatively high for the fixed administrative component $(\$ 1,648.75 /$ day, based on 1 day per week), primarily because of the rent, simulator upgrades and miscellaneous charges (office expenses and repairs) The next two most expensive activities included research $(\$ 916.00 /$ day based on 1 day $/$ wk) and resident training $(\$ 910.00 /$ day based on 0.5 day/wk), because of their extensive staffing requirements, coupled with lack of revenue.

While the overall resources dedicated to public relations activities, e.g., centre tours were not large, their per diem cost was large $(\$ 575.00 /$ day based on 0.25 day/wk), again, because of staffing requirements and the lack of revenues associated with this activity.

Crisis Management Training as a continuing medical education programme (CME) was open to physicians at a nominal cost. This net revenue did not cover the costs, but absorbed some of the expenses due to exten- sive staffing requirements (cost: $\$ 475.50$ per day based on 0.5 day/wk). The only activity resulting in a net profit was corporate training (profit of $\$ 562.50 /$ day based on 0.1 day/week). Because of the limited regional market for corporate training, an expansion of this application may prove difficult and insufficient to offset the costs of other simulator applications.

The simulation centre in Toronto is being used approximately 3.35 days per week. Given the large component of administrative activities and associated costs ( 1 day/week at $50 \%$ of operating costs) it may be useful to defray some of the expenses by leasing the centre to other users during the remaining time. Also the facilities could be offered to other health care departments (emergency medicine, trauma, etc.) to maximize the use of this expensive resource.

Substantial resources are required for the construction of a simulation centre $(\$ 665,000)$, mostly for capital equipment purchases. However, total operating costs $(\$ 167,250)$ consist mostly of salaries, and are unlikely to be recovered by revenue generating operations.

Institutions interested in instructor training should contact The Working Group for Crisis Management in Health Care to arrange and plan training (contact Dr. David Gaba, Department of Anaesthesia, Stanford University, phone (415) 858-3938; E-mail: gaba@stanford.edu)

Note: Above description applies to the construction and operation of the Canadian Simulation Centre for Human Performance and Crisis Management Training at Sunnybrook Health Science Centre only. Costs associated with such projects may vary and differ substantially and estimates should be verified independently. We cannot accept liability in conjunction with construction or maintenance of other facilities.

\section{References}

1 Good $M L$, Gravenstein JS, Mahla $M E$, et al. Can simulation accelerate the learning of basic anesthesia skills by beginning anesthesia residents? Anesthesiology 1992; 77: A1133.

2 Byrick RJ, McKnight DJ, Kurrek $M$, et al. Integration of crisis management using simulation-based education into postgraduate training: first year's experience. Can J Anaesth 1997; 44: A40B.

3 Kurrek $M M$, Fish KJ. Anaesthesia crisis resource management training: an intimidating concept, a rewarding experience. Can J Anaesth 1996; 43: 430-4.

4 Howard SK, Gaba DM, Fish KJ, Yang G, Sarnquist FH. Anesthesia crisis resource management training: teaching anesthesiologists to handle critical incidents. Aviat Space Environ Med 1992; 63: 763-70. 
5 Holzman RS, Cooper JB, Gaba DM, Pbilip JH, Small SD, Feinstein $D$. Anesthesia crisis resource management: real-life simulation training in operating room crises.

J Clin Anesth 1995; 7: 675-87.

6 Devitt $H$, Kurrek $M$, Coben $M$, et al. Testing the instrument: internal consistency during evaluation of performance in an anesthesia simulator. Anesthesiology 1996; 85: A931. 